\title{
AN INTRODUCTION TO THIS THEMATIC ISSUE
}

The Slovak Journal of Political Science (Slovenská politologická revue) celebrated 20 years of existence last year. Over the years, it has become an established journal with a focus on political science, international politics, and European issues in the Central European environment as well as further afield. This is proven by indexing it in several world-recognised databases (including SCOPUS, of which it has been part for three years). This is also reflected in the composition of individual issues that provide a wide range of academic topics well beyond the boundaries of this region and from authors working in various parts of the world. Over the past 20 years, the Journal has undergone a number of changes and modifications. The common feature of these efforts has always been our will to rise the quality of the Journal's content. In its twenty-first year of publication, we have decided to take the journal forward once again. The result of this intention is a theme-focused issue, and I hope other themes will follow in the near future. Our editorial board discussed and fine-tuned the focus of this issue for some time to prove Journal's progressive direction and innovative character within political science. Therefore, we opted for an issue on participatory budgeting as an innovative tool of political participation (not only) in the Central European environment. The call for papers was entitled "Participatory Budgeting in Central and Eastern Europe: A Useful Tool or Just a Fad?" The end result can be seen on these pages, and it is an output of a Slovak Research and Development Agency project entitled "APVV-19-0108: Innovations in Local Government Budgeting in Slovakia".

Participatory budgeting originated in Latin America (for more, see: Wampler, 2007; Dias, 2014) and gradually spread to other parts of the world. It is not surprising that it has begun to emerge in Europe, where it has established itself under specific national conditions. Participatory budgeting became an attractive topic for a research that would reflect European experiences with this tool. After directing our attention to the recent research on participatory budgeting in Central and Eastern Europe specifically, a significant progress could be observed despite short history of its implementation in this region. There have been a number of studies published, which, however, have tended to focus on specific countries (e.g. Kukučková, Bakoš, 2020; Szczepańska, Zagroba, Pietrzyk, 2021; Murray 
Svidroňová, Klimovský, 2022) rather than international comparative research (e.g. Nemec, Špaček, de Vries, 2022; Džinić, Murray Svidroňová, Markowska-Bzducha, 2016). In the Slovak context, it is already possible to classify research into individual case studies (e.g. Brix, 2018; Novák, Mikuš, 2020) or broader (summarizing) studies (e.g. Gašparíková, 2015; Mikuš, 2020; Garaj, Bardovič, 2020; Murray Svidroňová, Klimovský, 2022). In addition, the extension of this tool of participation to the level of regional governments allows to focus specifically on that level of policy making (e.g. Novák, 2021). Similarly, there are several studies examining participatory budgeting in the Czech Republic (e.g. Brabec, 2019; Kukučková, Bakoš, 2020; Gašparík, 2021); indeed, one of these appeared in the previous issue of this journal (Minárik, 2020). A similar situation can be seen when looking at Poland (e.g. Kozłowski, Bernaciak, 2022; Szczepańska, Zagroba, Pietrzyk, 2021). Among the Visegrad Four, only Hungary still lags in this area. Having said that, other Central and Eastern European countries have certainly been the subject of research interest.

This issue (Vol. 21, No. 2) of the Slovak Journal of Political Sciences is dedicated to participatory budgeting in Central and Eastern Europe. It contains five research articles, one summary article, and one book review. There is a particular focus on the Czech Republic in the work of Soňa Kukučková and Marie Poláchová (2021), and of Michal Soukop, Pavel Šaradín, and Markéta Zapletalová (2021). Kukučková and Poláchová examine the chosen method for decision-making in the framework of participatory budgeting and its role in relation to the actual participation of citizens, while Soukop, Šaradín, and Zapletalová examine the possible reasons for the failure of participatory budgeting in the specific case of the Prague 7 city district. There is a comparative article on Central and Eastern Europe by Dalibor Mikuš, Richard Brix, and Daniel Šmatlánek (2021), who focus on the Visegrad Four (Slovakia, the Czech Republic, Poland, and Hungary). This issue also includes an article by Maja Klun and Jože Benčina (2021), who search for possible factors influencing the potential implementation of participatory budgeting in Slovenia. In the last research article, Mirela Trtovac Šabović, Milos Milosavljevic, and Sladjana Benkovic (2021) examine the potential factors that lead to the low participation in terms of influence in financial decision-making. They look also on a link between the identified factors and the level of distrust in politics and society.

This issue also includes a summary article by Daniel Klimovský, Veronica Junjan, and Juraj Nemec (2021) bringing an overall view at matters of participatory budgeting in the Central and Eastern European context. 
They focus mostly on current developments in implementation of PB while considering the extent of research conducted in this area. In addition, this article summarizes the insights provided by the aforementioned research articles.

The final part of this issue enriches this edition with is a book review of "International Trends in Participatory Budgeting: Between Trivial Pursuits and Best Practices" (edited by de Vries, Nemec, and Špaček, 2022) which was written by Martina Balážová (2021).

This thematic issue confirms the Journal's international scope as it was co-edited by three guest editors who are internationally well-known scholars. Daniel Klimovský is an associate professor in Political Science at the Department of Political Science, Faculty of Arts, Comenius University in Bratislava (Slovakia). Moreover, he is a part-time researcher at the Science and Research Centre, Faculty of Economics and Administration, University of Pardubice (Czech Republic). His research is focused on participatory governance, political representation, and quality of public service delivery. Veronica Junjan is an assistant professor in Public Management with the Section of Public Administration, Faculty of Behaviour, Management and Social Sciences, University of Twente (Netherlands). Generally, her research addresses administrative and governance reforms. Currently, her research interest focuses on analysing changes in tasks of government from the perspective of new technological developments, with a particular focus on administrative capacity building for resilience, at national as well as local levels. Another expert participating at this issue is Juraj Nemec, a fulltime professor of Public Finance and Public Management in the Faculty of Economics and Administration, Masaryk University in Brno (Czech Republic), and a part-time professor in the Faculty of Economics, Matej Bel University in Banská Bystrica (Slovakia). His research is focused on public sector management, public finance and public procurement.

I believe that the reader find this thematic issue interesting and enriching today's expert and academic debate on matters of civic participation at local level. The ambition of this issue is to become an important source of new findings, or at least a stepping-stone for further research into participatory budgeting in Central and Eastern Europe and beyond.

Jakub Bardovič

Editor-in-Chief

Faculty of Social Sciences, University of Ss. Cyril and Methodius in Trnava, Slovakia, E-mail: jakub.bardovic@ucm.sk. ORCID: 0000-0002-4364-0353 


\section{Acknowledgement:}

This work was supported by the Slovak Research and Development Agency under the Grant No. APVV-19-0108: "Innovations in Local Government Budgeting in Slovakia".

\section{REFERENCES}

BRABEC, D. (2019). Participatory Budgeting in the Czech Republic between 2014 and 2018. In: Annales Universitatis Mariae-Curie Skłodowska, sectio K - Politologia. Vol. 26, No. 2. pp. 91-101. DOI: http://dx.doi. org/10.17951/k.2019.26.2.91-101.

BRIX, R. (2018). Participatívny rozpočet v podmienkach SR. In: Palúš, I., Mital', O. and Žofčinová, V. eds. Verejná správa v súčasnom demokratickom a právnom štáte. Čast' 2. Košice: ŠafárikPress. pp. 278-286.

DIAS, N. (2014). 25 years of Participatory Budgets in the world: A new social and political movement? In: Hope for democracy - 25 years of participatory budgeting worldwide. São Brás de Alportel: In Loco Association. pp. 2127.

DŽINIĆ, J., MURRAY SVIDROŇOVÁ, M. and MARKOWSKA-BZDUCHA, E. (2016). Participatory Budgeting: A Comparative Study of Croatia, Poland, and Slovakia. In: The NISPAcee Journal of Public Administration and Policy. Vol. 9, No. 1, pp. 31-56. DOI: https://doi.org/10.1515/nispa-2016-0002. GARAJ, M. and BARDOVIČ, J. (2020). Participatory Budgeting: The Case of the Slovak Republic. In: Annales Universitatis Mariae-Curie Skłodowska, sectio $K$ - Politologia. Vol. 27, No. 2, pp. 59-73. DOI: https://doi. org/10.17951/k.2020.27.2.59-73.

GAŠPARÍK, J. (2021). Brnenský participatívny rozpočet $\mathrm{z}$ pohladu teoretických východísk. In: Cibík, L., Brix, R., Novák, M. and Michal, S. eds. PUBLICY 2021 - čast' II. Zborník príspevkov z medzinárodnej vedeckej konferencie. Trnava: Fakulta sociálnych vied, Univerzita sv. Cyrila a Metoda v Trnave, pp. 86-96.

GAŠPARÍKOVÁ, J. (2015). Participative Budgeting - Various Approaches in Slovakia. In: Review of Applied Socio- Economic Research. Vol. 10, No. 2. pp. 45-48.

KOZŁOWSKI, A. R. and BERNACIAK, A. (2022). Participatory Budgeting in Poland. In: de Vries, M. S., Nemec, J. and Špaček, D. eds. International Trends in Participatory Budgeting. Between Trivial Pursuits and Best Practices. Cham: Palgrave Macmillan. pp. 163-185. DOI: https://doi. org/10.1007/978-3-030-79930-4_9. 
KUKUČKOVÁ, S. and BAKOŠ, E. (2020). Does Participatory Budgeting Bolster Voter Turnout in Elections? The Case of the Czech Republic. In: NISPAcee Journal of Public Administration and Policy. Vol 12, No. 2. pp. 109-129. DOI: https://doi.org/10.2478/nispa-2019-0016.

MIKUŠ, D. (2020). Participatívny rozpočetako nástroj občianskej participácie. In: Hotváth, P. and Machyniak, J. eds. PUBLICY 2020 I. - 30 rokov verejnej správy. Trnava: Fakulta sociálnych vied, Univerzita sv. Cyrila a Metoda v Trnave. pp. 197-203.

MINÁRIK, P. (2020). Participatory Budgeting and Traditional Participation in Czech Municipalities. In: Slovak Journal of Political Sciences. Vol. 20, No. 1, pp. 29-47. DOI: https://doi.org/10.34135/sjps.200102.

MURRAY SVIDROŇOVÁ, M. and KLIMOVSKÝ, D. (2022). Participatory Budgeting in Slovakia: Recent Development, Present State, and Interesting Cases. In: De Vries M. S., Nemec J. and Špaček D. eds. International Trends in Participatory Budgeting. Cham: Palgrave Macmillan, pp. 247-269. DOI: https://doi.org/10.1007/978-3-030-79930-4_13.

NEMEC, J., ŠPAČEK, D. and DE VRIES, M. S. (2022). Unraveled Practices of Participatory Budgeting in European Democracies. In: De Vries, M. S., Nemec, J. and Špaček, D. eds. International Trends in Participatory Budgeting: Between Trivial Pursuits and Best Practices. Cham: Palgrave Macmillan, pp. 287-313. DOI: https://doi.org/10.1007/978-3-03079930-4_15.

NOVÁK, M. (2021). Participatívne rozpočtovanie samosprávnych krajov v podmienkach Slovenskej republiky. In: Čajková, A., Klimovský, D., Mulinová, N. B. eds. Sociálne vedy z perspektívy mladých vedeckých pracovníkov V. Zborník príspevkov z medzinárodnej vedeckej konferencie doktorandov a mladých vedeckých pracovníkov. Trnava: Fakulta sociálnych vied, Univerzita sv. Cyrila a Metoda v Trnave. pp. 31-42.

NOVÁK, M. and MIKUŠ, D. (2020). Participatory budget as a tool of modern management methods in local government. In: Politics and Knowledge: New Trends in Social Research: proceedings of 7th Academos Conference 2020 International Conference. Bologna : Filodiritto Publisher. pp. 292-301. SZCZEPAŃSKA, A., ZAGROBA, M. and PIETRZYK, K. (2021). Participatory Budgeting as a Method for Improving Public Spaces in Major Polish Cities. In: Social Indicators Research. DOI: https://doi.org/10.1007/ s11205-021-02831-3.

WAMPLER, B. (2007). A Guide to Participatory Budgeting. In: Shah, A. (ed.): Participatory Budgeting: Public Sector, Governance and Accountability Series. Washington, D. C.: The World Bank. pp. 21-54. 


\section{Content of the Thematic Issue:}

BALÁŽOVÁ, M. (2021). De Vries, M. S., Nemec, J., and Špaček, D. (2022). International Trends in Participatory Budgeting: Between Trivial Pursuits and Best Practices, Cham: Palgrave Macmillan, 2022, ISBN 9783-030-79929-8. In: Slovak Journal of Political Sciences. Vol. 21, No. 2, pp. 256-261. https://doi.org/10.34135/sjps.210207.

KLIMOVSKÝ, D., JUNJAN, V. and NEMEC, J. (2021). Selected Factors Determining the Adoption and Use of Participatory Budgeting in Central and Eastern Europe. In: Slovak Journal of Political Sciences. Vol. 21, No. 2, pp. 230-255. DOI: https://doi.org/10.34135/sjps.210206.

KLUN, M. and BENČINA, J. (2021). Predictors, Determinant Groups, and Participatory Budgeting. In: Slovak Journal of Political Sciences. Vol. 21, No. 2, pp. 186-208. DOI: https://doi.org/10.34135/sjps.210204.

KUKUČKOVÁ, S. and POLÁCHOVÁ, M. (2021). The Impact of the D21 Method and Its Modification on Citizens' Participation in Participatory Budgeting. The Case of the Czech Republic. In: Slovak Journal of Political Sciences. Vol. 21, No. 2, pp. 117-138. DOI: https://doi.org/10.34135/sjps.210201. MIKUŠ, D., BRIX, R. and ŠMATLÁNEK, D. (2021). Specifications of Participatory Budgeting in Visegrad Group States and Possible Implementations for Slovakia. In: Slovak Journal of Political Sciences. Vol. 21, No. 2. pp. 161185. DOI: https://doi.org/10.34135/sjps.210203.

ŠABOVIC, M. T., MILOSAVLJEVIĆ, M. and BENKOVIĆ, S. (2021). Participation of Citizens in Public Financial Decision-Making in Serbia. In: Slovak Journal of Political Sciences. Vol. 21, No. 2, pp. 209-229. DOI: https://doi. org/10.34135/sjps.210205.

SOUKOP, M., ŠARADÍN, P. and ZAPLETALOVÁ, M. (2021). Participatory Budgeting: Case Study of Possible Causes of Failures. In: Slovak Journal of Political Sciences. Vol. 21, No. 2, pp. 139-160. DOI: https://doi. org/10.34135/sjps.210202. 